\title{
PENGARUH MOTIVASI TERHADAP KINERJA KARYAWAN PADA PT. DALIA KUSUMA BANDUNG
}

\author{
EGA KRISTINA \\ Politeknik Piksi Ganesha
}

A B S T R A C T

The study aims to determine the effect of motivation on employee performance of PT. Dalia Kusuma Bandung, the method used is quantitative method. Data collection techniques that writers do is observation, questionnaires, interviews and literature.

From the results of the study showed that motivation $(X)$ to give a contribution of $63.68 \%$ on employee performance $(Y)$ in PT. Dalia Kusuma Bandung and the remaining $36.32 \%$ influenced by other factors not examined by the author.

The problems faced are: Employees feel uneasy in the work because of the unavailability of health insurance from this company and working at the company, has not been able to guarantee the employee's life in the old days

Suggestion: Companies are more concerned about health insurance and annuities as well as companies providing training - training for employees to hone the abilities and skills and experience needed in order to complete the job properly.

Keywords: Motivation; Employee performance.

\section{A. PENDAhuluan}

Pada saat ini perkembangan usaha bisnis sangat berkembang pesat sehingga dengan sendirinya muncul tingkat persaingan yang semakin tajam diantara para pengusaha (perusahaan). Hal ini menyebabkan para pengusaha meningkatkan kemampuan sumber daya manusia agar dapat siap bersaing dengan perusahaan lain dan dapat meningkatkan kinerja sumber daya manusia itu sendiri. Untuk menerapkan hal tersebut perlu adanya motivasi kinerja.

Motivasi kerja menjadi hal yang penting bagi setiap perusahaan, terutama manfaat bagi karyawan dan perusahaan. Motivasi akan mendorong karyawan untuk lebih berprestasi dan produktif. Begitu pula motivasi dalam perusahaan dalam rangka peningkatan produksi dan penekanan biaya melalui perbaikan sikap dan tingkah laku karyawan.

Dengan adanya motivasi kerja maka dapat dilihat pengaruhnya dari kinerja karyawan. Dimana karyawan akan melakukan tindakan atas dasar keinginan untuk berprestasi dan memperoleh jabatan lebih tinggi di perusahaan.

Tujuan yang ingin di capai penulis dalam penelitian ini adalah untuk melihat dan mengetahui apakah ada motivasi kerja dengan dengan variabel kebutuhan akan prestasi, kebutuhan akan kekuasaan, kebutuhan akan afiliasi secara parsial dengan kinerja karyawan PT.Dalia Kusuma Bandung. Serta untuk melihat dan mengetahui apakah ada motivasi kerja dengan variabel kebutuhan akan prestasi, kebutuhan akan kekuasaan, kebutuhan afiliasi secara bersama-sama dengan kinerja karyawan PT.Dalia Kusuma Bandung.
Berdasarkan permasalahan tersebut di atas dan fakta-fakta yang peneliti temukan di lapangan, maka peneliti merasa tertarik untuk meneliti lebih jauh mengenai motivasi terhadap kinerja pegawai yang dituangkan dalam bentuk usulan penelitian dengan judul : " PENGARUH MOTIVASI TERHADAP KINERJA KARYAWAN PT.DALIA KUSUMA BANDUNG “.

\section{B. TUJUAN DAN KEGUNAAN PENELITIAN : Tujuan :}

a. Untuk mengetahui bagaimana motivasi kerja yang dilakukan di PT.Dalia Kusuma Bandung.

b. Untuk mengetahui kinerja karyawan di PT.Dalia Kusuma Bandung.

c. Untuk mengetahui seberapa besar pengaruh motivasi kerja terhadap kinerja karyawan PT.Dalia Kusuma Bandung.

d. Untuk mengetahui bagaimana permasalahn motivasi kerja terhadap kinerja karyawan PT.Dalia Kusuma Bandung.

\section{Kegunaan :}

Adapun hal yang menjadi kegunaan dalam pengerjaan analisa penelitian ini adalah sebagai berikut:

1. Bagi Bagian Akademis

a. Sebagai tambahan informasi dan referensi tentang hal-hal yang berkaitan dengan penelitian dan untuk memperkaya wawasan pengetahuan ilmiah sekaligus 
sebagai informasi dalam menunjang penelitian di masa yang akan datang khususnya mengenai pengaruh motivasi terhadap kinerja karyawan PT.Dalia Kusuma Bandung.

b. Sebagai solusi dalam proses persoalan masalah yang timbul di PT.DALIA KUSUMA Bandung.

2. Bagi Peneliti

a. Sebagai salah satu syarat dalam menyelesaikan studi akademis.

b. Menambah pengalaman dalam proses penelitian terhadap suatu sistem informasi.

c. Sebagai motivator untuk terus berkreasi dan berwawasan tinggi demi mencapai target yang diinginkan.

d. Sebagai acuan untuk proses kegiatan penelitian di masa yang akan datang dan menjadi sebuah ilmu pengetahuan yang bermanfaat.

3. Bagi perusahaan

a. Untuk memberikan informasi sebagai bahan masukan dan pertimbangan dalam upaya peningkatan kinerja para karyawan melalui motivasi.

b. Merupakan bahan masukan bagi karyawan PT. Dalia Kusuma sebagai mengevaluasi disi khususnya yang terkait dengan prestasi kerja untuk meningkatkan kinerja.Menambah pengetahuan dan wawasan mengenai motivasi.

c. Sebagai motivator untuk terus berkreasi tinggi demi mencapai target yang diinginkan.

d. Sebagai acuan untuk proses kegiatan penelitian di masa yang akan datang dan menjadi sebuah ilmu pengetahuan yang bermanfaat.

\section{KAJIAN PUSTAKA}

\section{Manajemen Sumber Daya Manusia}

Manajemen sumber daya manusia merupakan bagian dari setiap perusahaan atau setiap organisasi yang bisa anda temukan sehari - hari. Istilah manajemen sumber daya manusia disisi lain merujuk pada departemen yang menaungi kerja sistem hubungan antar pekerja - pekerja disebuah perusahaan, atau organisasi. Jadi, departemen ini terlibat dalam segala hal yang berkaitan dengan kesejahteraan, pendidikan karyawan, perekrutan tenaga kerja, dan analisis terhadap kebijakan perusahaan yang berkaitan dengan karyawan.

Manajemen sumber daya manusia menurut Bambang Wahyudin (2002: 1) "manajemen sumber daya manusia adalah ilmu dan seni atau proses memperoleh, memajukan atau mengembangkan, dan memelihara sumber daya manusia yang kompeten sedemikian rupa, sehingga tujuan organisasi dapat tercapai dengan efisiensi dan ada kepuasan pada diri pribadi - pribadi yang bersangkutan". Sedangkan definisi lain menurut Edwin B. Flippo dalam buku Bambang Wahyudi Manajemen Sumber Daya Manusia (2002 : 9) "manajemen sumber daya manusia merupakan perencanaan, pengorganisasian, pengarahan, dan pengawasan dari pada pengembangan, pemberian balas jasa, pengintegrasian pemeliharaan, dan pemisahan sumber daya manusia ke suatu titik akhir dimana tujuantujuan perorangan,organisasi dan masyarakat". Selanjutnya menurut Malayu S.P Hasibuan (2002 : 10) menjelaskan bahwa "manajemen sumber daya manusia adalah ilmu dan seni mengatur hubungan dan peranan tenaga kerja agar efektif dan efisien membantu terwujudnya tujuan perusahaan, karyawan dan masyarakat".

\section{Fungsi - fungsi manajemen sumber daya manusia}

Manajemen sumber daya manusia mengurus dan menetapkan tenaga kerja pada kedudukan yang tepat, menyelenggarakan latihan bagi para karyawan, mengkoordinir pemindahan, mengatur promosi dan memberhentikan karyawan agar dapat melaksanakan tugasnya dengan baik dan benar, disiplin serta tanggung jawab.

Fungsi manajemen sumber daya manusia menurut Malayu S.P Hasibuan (2001 : 21 - 22).

1. Fungsi - fungsi Manajerial

a. Perencanaan (Planning)

b. Pengorganisasian (Organizing)

c. Pengarahan (Directing)

d. Pengendalian (Controlling)

2. Fungsi - fungsi Operasional

Menurut Malayu S.P. Hasibuan (2001 : 22 -23)

a. Pengadaan (Procurement)

b. Pengembangan (Development)

c. Kompensasi (Compensation)

d. Pengintegrasian (Integration)

e. Pemeliharaan (Maintenance)

Dengan adanya fungsi - fungsi manajemen sumber daya manusia dapat dikatakan bahwa pelaksanaan fungsi tersebut diarahkan pada optimalisasi bagi kedua belah pihak dalam suatu organisasi di mana suatu kerja sama dalam kondisi yang dapat mendorong setiap karyawan untuk memberikan sumbangan sumbangan sebaik mungkin bagi efektifnya suatu organisasi.

Manajemen Sumber Daya Manusia mempunyai peranan penting dalam pencapaian tujuan organisasiakan terwujud bila organisasi mampu memberdayakan sumber daya manusianya, sehingga memberi energy secara optimal yang membuatnya mampu meningkatkan kinerja dan efektivitas kerjanya. (Veranita, 2012)

\section{Motivasi}

Membahas mengenai pengertian motivasi, peneliti akan mengemukakan pengertian motivasi terlebih dahulu. Motivasi merupakan kegiatan yang 
penting yang mengakibatkan, menyalurkan, dan memelihara perilaku manusia. Motivasi merupakan subyek yang penting bagi pimpinan karena pemimpin harus bekerja dengan dan melalui orang lain. Pemahaman dan pengertian mengenai motivasi dapat peneliti jabarkan berdasarkan beberapa pendapat para ahli.

Menurut Effendi yang dikutip oleh Manullang dan Manullang (2004:193) dalam bukunya Manajemen Personalia mengemukakan bahwa: Motivasi adalah kegiatan memberikan dorongan pada seseorang atau diri sendiri untuk mengambil suatu tindakan yang dikehendaki. Jadi motivasi berarti membangkitkan seseorang atau diri sendiri untuk berbuat sesuatu dalam rangka mencapai suatu kepuasan dan tujuan.

Pengertian motivasi menurut Gibson ( FX. Suwarto, Drs., MS., Perilaku Keorganisasian, Penerbitan Universitas Atma Jaya Yogyakarta, 1999, halaman 77 ) adalah suatu konsep yang menguraikan tentang kekuatan-kekuatan yang ada dalam diri karyawan yang memulai dan mengarahkan perilaku.

Pengertian motivasi menurut Drs. The Liang Gie cs ( Kolonel Kal. Susilo Martoyo, S.E., Manajemen Sumber Daya Manusia, BPFE Yogyakarta, 1994, halaman 154) adalah pekerjaan yang dilakukan oleh seorang manajer dalam memberikan inspirasi, senabgat dan dorongan kepada orang lain, dalam hal ini karyawannya, untuk mengambil tindakan-tindakan. Pemberian dorongan ini bertujuan untuk menggiatkan orang-orang atau karyawan agar mereka bersemangat dan dapat mencapai hasil sebagaiman dikehendaki dari orang-orang tersebut.

\section{Jenis Motivasi}

Seorang pemimpin dalam memotivasi bawahan menggunakan jenis motivasi yang berbeda-beda sesuai dengan situasi dan kondisi yang sedang dihadapi saat itu.

Menurut Hasibuan (2003:99) dalam bukunya yang berjudul Organisasi Dan Motivasi menyatakan bahwa ada dua jenis motivasi sebagai berikut :

1. Motivasi Positif (Insentif Positif)

Manajer memotivasi bawahan dengan memberikan hadiah kepada mereka yang berprestasi baik. Dengan motivasi positif ini semangat kerja bawahan akan meningkat, karena manusia pada umumnya senang menerima yang baik-baik saja.

2. Motivasi Negatif (Insentif Negatif)

Manajer memotivasi bawahan dengan memberikan hukuman kepada mereka yang pekerjaannya kurang baik (prestasi rendah). Dengan motivasi negatif ini semangat kerja bawahan dalam jangka waktu pendek akan meningkat, karena mereka takut dihukum, tetapi untuk jangka waktu panjang dapat berakibat buruk.
Dari penjelasan diatas maka dapat diketahui bahwa motivasi positif (insentif positif) akan memicu semangat kerja pegawai dalam jangka waktu panjang dan motivasi negatif (insentif negatif) hanya memicu semangat kerja dalam jangka waktu pendek tetapi untuk jangka waktu panjang akan berakibat buruk.

\section{Alat-Alat Motivasi}

Penggunaan masing-masing alat motivasi ini dengan segala bentuknya haruslah mempertimbangkan situasi dan orangnya sebab pada hakekatnya individu adalah berbeda dengan yang lainnya.

Menurut Hasibuan (2003:99) dalam bukunya yang berjudul Organisasi Dan Motivasi menyatakan tentang prinsip pelaksanaan motivasi yaitu:

\section{Material Insentif}

Alat-alat motivasi yang diberikan itu berupa uang dan atau barang yang mempunyai nilai pasar, jadi memberikan kebutuhan ekonomis. Misalnya : kendaraan, rumah, dan lain-lain.

2. Non Material Insentif

Alat motivasi yang diberikan itu berupa barang atau benda yang tidak ternilai, jadi hanya memberikan kepuasan atau kebanggaan rohani saja. Misalnya : mendali, piagam, bintang jasa, dan lain-lain.

Kombinasi Material dan Non Material Insentif

Alat motivasi yang diberikan itu berupa materil (uang dan barang) dan non materil (mendali atau piagam), jadi memenuhi kebutuhan ekonomis dan kepuasan atau kebanggaan rohani.

Pendapat diatas menerangkan bahwa kebutuhan bersifat materil adalah besar upah dan penerimaan-penerimaan lain yang dapat berupa uang, beras, gula, rokok, dan sebagainya. Sedangkan kebutuhan yang bersifat non materil merupakan kebutuhan-kebutuhan yang diperlukan bilamana dipenuhi akan dapat menimbulkan kepuasan tapi kebutuhan ini dapat bersifat materil, misalnya peasaan harga diri, rasa kebangaan, dipenuhinya keinginan berpartisipasi dan sebagainya.

\section{Teori Motivasi}

Didalam memotivasi pegawai juga diperlukan teori motivasi untuk lebih memperjelas makna dan manfaat motivasi dalam meningkatkan semangat kerja pegawai dalam pelaksanaan pencapaian tujuan untuk lebih memperjelasnya maka akan diuraiakan teori motivasi sebagai berikut :

1. Teori Pemenuhan Kebutuhan Pegawai

Pemenuhan kebutuhan pegawai merupakan fundamental yang mendasari perilaku kerja. Kita tidak mungkin dapat memotivasi kerja pegawai tanpa memperhatikan apa yang dibutuhkannya. 
Abraham Maslow mengemukakan hirarki kebutuhan pegawai sebagai berikut :

a. Kebutuhan Fisiologis, yaitu kebutuhan makan, minum, perlindungan fisik, bernafas, dan sexual. Kebutuhan ini merupakan kebutuhan yang paling mendasar. Dalam hubungan dengan kebutuhan ini pemimpin perlu memberikan gaji yang layak kepada pegawai.

b. Kebutuhan rasa aman, yaitu kebutuhan perlindungan dari ancaman, bahaya dan lingkungan kerja. Dalam hubungan kebutuhan ini, pemimpin perlu memberikan tunjangan kesehatan, asuransi kecelakaan, perumahan, dan dana pensiun.

c. Kebutuhan sosial atau rasa memiliki, yaitu kebutuhan untuk diterima dalam kelompok unit kerja, berafiliasi, berinteraksi, serta rasa dicintai dan mencintai. Dalam hubungan dengan kebutuhan ini, pemimpin perlu menerima eksistensi atau keberadaan pegawai sebagai anggota kelompok kerja, melakukan interaksi kerja yang baik dan hubungan kerja yang harmonis.

d. Kebutuhan harga diri, yaitu kebutuhan untuk dihormati dan dihargai orang lain. Dalam hubungan dengan kebutuhan ini, pemimpin tidak boleh sewenang-wenang memperlakukan pegawai karena mereka perlu dihormati, diberikan penghargaan terhadap prestasi kerjanya.

e. Kebutuhan aktualisasi diri, yaitu kebutuhan untuk mengembangkan diri dan potensi, mengemukakan ideide, memberikan penilaian, kritik, dan berprestasi. Dalam hubungannya dengan kebutuhan ini, pemimpin perlu memberikan kesempatan kepada pegawai bawahan agar mereka dapat mengaktualisasikan diri secara baik dan wajar di perusahaan.

Selanjutnya, Abraham Maslow berpendapat bahwa orang dewasa (pegawai bawahan) secara normal harus terpenuhi minimal 85 persen kebutuhan fisiologis, 70 persen kebutuhan rasa aman, 50 persen kebutuhan sosial, 40 persen kebutuhan penghargaan, dan 15 persen kebutuhan aktualisasi diri. Jika tidak terpenuhi maka pegawai tersebut akan mengalami konflik diri, keluarga, dan bisa juga menjadi penyebab terjadinya konflik kerja. Dengan demikian, jika kebutuhan pegawai tidak terpenuhi, pemimpin akan mengalami kesulitan dalam memotivasi kerja pegawai.

\section{Teori komunikasi persuasif}

Teori komunikasi persuasif merupakan salah satu teknik memotivasi kerja pegawai yang dilakukan dengan cara mempengaruhi pegawai secara ekstralogis. Teknik ini dirumuskan: "AIDDAS"
A = Attention (Perhatian)
I $\quad=$ Interest (Minat)
$\mathrm{D}=$ Desire
(Hasrat)
$\mathrm{D}=$ Decision (Keputusan)
A $\quad=$ Action (Aksi/Tindakan)

$\mathrm{S} \quad=$ Satisfaction (Keputusan)

Penggunaannya, pertama kali pemimpin harus memberikan perhatian kepada pegawai tentang pentingnya tujuan dari suatu pekerjaan agar timbul minat pegawai terhadap pelaksanaan kerja, jika telah timbul minatnya maka hasratnya menjadi kuat untuk mengambil keputusan dan melakukan tindakan kerja dalam mencapai tujuan yang diharapkan oleh pemimpin. Dengan demikian, pegawai akan bekerja dengan motivasi tinggi dan merasa puas terhadap hasil kerjanya.

\section{Model-Model Motivasi}

Perkembangan teori manajemen juga mencakup model-model motivasi yang berbeda. Berikut ini akan dibahas tiga model motivasi dengan urutan atas dasar kemunculannya, yaitu model tradisional, model hubungan manusiawi, dan model sumber daya manusia.

\section{Model tradisional}

Model tradisional dari motivasi berhubungan dengan Frederick Taylor dan aliran manajemen ilmiah. Model ini mengisyaratkan bahwa manajer menentukan bagaimana pekerjaan-pekerjaan harus dilakukan dan digunakan sistem pengupahan insentif untuk memotivasi para pekerja lebih banyak berproduksi, lebih banyak menerima penghasilan.

Pandangan tradisional menganggap bahwa para pekerja pada dasarnya malas dan hanya dapat dimotivasi dengan penghargaan berwujud uang. Dalam banyak situasi pendekatan ini cukup efektif. Sejalan dengan meningkatknya efisiensi, karyawan yang dibutuhkan untuk tugas tertentu dapat dikurangi. Lebih lanjut, manajer mengurangi besarnya upah insentif. Pemutusan hubungan kerja menjadi biasa dan pekerja akan mencari keamanan/jaminan kerja daripada hanya kenaikan upah kecil dan sementara.

2. Model hubungan manusiawi

Banyak praktek manajemen merasakan bahwa pendekatan tradisional tidak memadai. Elton Mayo dan para peneliti hubungan manusiawi lainnya menemukan bahwa kontak-kontak sosial karyawan pada pekerjaannya adalah juga penting dan bahwa kebosanan dan tugas- tugas yang bersifat pengulangan adalah faktor-faktor pengurang motivasi. Mayo dan kawankawan juga percaya bahwa manjer dapat memotivasi bawahan melalui pemenuhan kebutuhan-kebutuhan sosial mereka dan membuat mereka merasa berguna dan penting. Sebagai hasilnya, para karyawan diberi berbagai kebebasan untuk membuat keputusan sendiri dalam pekerjaannya. Perhatian yang lebih besar diarahkan pada kelompok-kelompok kerja organisasi informal. Lebih banyak informasi disediakan untuk karyawan tentang perhatian manajer dan operasi organisasi 
3. Model sumber daya manusia

Kemudian para teoritisi seperti McGregor dan Maslow, dan para peneliti seperti Argyris dan Likert, melontarkan kritik kepada model hubungan manusiawi dan mengemukakan pendekatan yang lebih "sophisticated" untuk memanfaatkan para karyawan. Model ini menyatakan bahwa para karyawan dimotivasi oleh banyak faktor, tidak hanya uang atau keinginan untuk mencapai kepuasan, tetapi juga kebutuhan untuk berprestasi dan memperoleh pekerjaan yang berarti.

Mereka beralasan bahwa kebanyakan orang telah dimotivasi untuk melakukan pekerjaan secara baik dan bahwa mereka tidak secara otomatis melihat pekerja sebagai sesuatu yang tidak dapat menyenangkan. Mereka mengemukakan bahwa para karyawan lebih menyukai pemenuhan kepuasan dari suatu prestasi kerja yang baik. Jadi, para karyawan dapat diberi tanggung jawab yang lebih besar untuk pembuatan keputusan- keputusandan pelaksaan tugas-tugas.

\section{Prinsip-Prinsip Motivasi}

Motivasi yang diberikan oleh atasan kepada bawahan, tentunya harus mengunakan pedoman atau dengan kata lain prinsip-prinsip yang harus dijadikan pedoman oleh atasan untuk memotivasi bawahannya Menurut Mangkunegara (2004:100) dalam bukunya yang berjudul "Manajemen Sumber Daya Manusia Perusahaan", mengemukan Prinsip-prinsip dalam memotivasi kerja pegawai adalah sebagai berikut :

1. Prinsip partisipasi

2. Prinsip komunikasi

3. Prinsip mengakui andil bawahan

4. Prinsip pendelegasian wewenang

5. Prinsip memberikan perhatian

\section{Kinerja Pegawai}

Kinerja pegawai adalah hasil kerja perseorangan dalam suatu organisasi. Tercapainya tujuan organisasi tidak bisa dilepaskan dari sumber daya yang dimiliki oleh organisasi yang digerakkan atau dijalankan pegawai yang berperan aktif sebagai pelaku dalam upaya mencapai tujuan organisasi tersebut. Berikutnya ada beberapa pendapat tentang kinerja yang akan diuraikan oleh peneliti.

Kinerja menurut Prawirosentono yang dikutip oleh Pasolong (2007:176), dalam bukunya Teori Administrasi Publik menyatakan bahwa : Kinerja adalah hasil kerja yang dapat dicapai oleh pegawai atau sekelompok pegawai dalam suatu organisasi, sesuai dengan wewenang dan tanggung jawab masing-masing, dalam upaya mencapai tujuan organisasi bersangkutan secara legal, tidak melanggar hukum dan sesuai dengan moral dan etika.
Pengertian Kinerja menurut Mangkunegara (2002:67) dalam bukunya yang berjudul Manajemen Sumber Daya Manusia Perusahaan, mengatakan bahwa : "Kinerja merupakan hasil secara kualitas dan kuantitas yang dicapai oleh seseorang dalam melaksanakan fungsinya sesuai dengan tanggungjawab yang diberikan kepadanya".

Lembaga Administrasi Indonesia disingkat LAN-RI dalam Pasolong (2007:175), dalam bukunya Teori Administrasi Publik merumuskan kinerja sebagai berikut: "Kinerja adalah gambaran mengenai tingkat pencapaian pelaksanaan suatu kegiatan, program, kebijaksanaan dalam mewujudkan sasaran, tujuan, visi, dan misi organisasi”".

Selanjutnya peneliti akan kemukakan pengertian kinerja menurut T. R. Mitchel dalam buku Sedarmayanti (2001:51) yang berjudul Manajemen Sumber Daya Manusia dan Produktivitas Kerja, menjelaskan bahwa :

$$
\text { Performance }=\text { ability } \mathrm{x} \text { motivation }
$$

Maksudnya untuk mendapatkan gambaran tentang kinerja seseorang, maka diperlukan pengkajian khusus tentang kemampuan dan motivasi.

Menurut Sinambela dkk yang dikutip oleh Pasolong dalam bukunya yang berjudul Teori Administrasi Publik, mengatakan bahwa : "Kinerja pegawai sebagai kemampuan pegawai dalam melakukan keahlian tertentu".

Pengertian kinerja menurut Robbins dalam buku Pasolong yang berjudul Teori Administrasi Publik, mengatakan bahwa : "Kinerja adalah hasil evaluasi terhadap pekerjaan yang dilakukan oleh pegawai dibandingkan dengan kriteria yang telah ditetapkan sebelumnya".

\section{Indikator Kinerja Pegawai}

Kinerja pegawai secara objektif dan akurat dapat dievaluasi melalui tolak ukur tingkat kinerja. Pengukuran tersebut berarti memberi kesempatan bagi para pegawai untuk mengetahui tingkat kinerja mereka. Memudahkan pengkajian kinerja pegawai, lebih lanjut Mitchel dalam buku Sedarmayanti (2001:51) yang berjudul Manajemen Sumber Daya Manusia dan Produktivitas Kerja, mengemukakan indikator-indikator kinerja yaitu sebagai berikut :

1. Kualitas Kerja (Quality of work)

2. Ketetapan Waktu (Pomptnees)

3. Inisiatif (Initiative)

4. Kemampuan (Capability)

5. Komunikasi (Communication) 
Indikator kinerja pegawai di atas akan dibahas di bawah untuk lebih mempermudah dalam memahami kinerja pegawai, yaitu sebagai berikut :

1. Kualitas Kerja (Quality of work) adalah kualitas kerja yang dicapai berdasarkan syarat-syarat kesesuaian dan kesiapannya yang tinggi pada gilirannya akan melahirkan penghargaan dan kemajuan serta perkembangan organisasi melalui peningkatan pengetahuan dan keterampilan secara sistematis sesuai tuntutan ilmu pengetahuan dan teknologi yang semakin berkembang pesat.

2. Ketetapan Waktu (Pomptnees) yaitu berkaitan dengan sesuai atau tidaknya waktu penyelesaian pekerjaan dengan target waktu yang direncanakan. Setiap pekerjaan diusahakan untuk selesai sesuai dengan rencana agar tidak mengganggu pada pekerjaan yang lain.

3. Inisiatif (Initiative) yaitu mempunyai kesadaran diri untuk melakukan sesuatu dalam melaksanakan tugastugas dan tanggung jawab. Bawahan atau pegawai dapat melaksanakan tugas tanpa harus bergantung terus menerus kepada atasan.

4. Kemampuan (Capability) yaitu diantara beberapa faktor yang mempengaruhi kinerja seseorang, ternyata yang dapat diintervensi atau diterapi melalui pendidikan dan latihan adalah faktor kemampuan yang dapat dikembangkan.

5. Komunikasi (Communication) merupakan interaksi yang dilakukan oleh atasan kepada bawahan untuk mengemukakan saran dan pendapatnya dalam memecahkan masalah yang dihadapi. Komunikasi akan menimbulkan kerjasama yang lebih baik dan akan terjadi hubungan- hubungan yang semangkin harmonis diantara para pegawai dan para atasan, yang juga dapat menimbulkan perasaan senasib sepenanggungan.

6. Pendapat tersebut mengatakan bahwa untuk mendapatkan kinerja pegawai yang optimal yang menjadi tujuan organisasi harus memperhatikan aspek-aspek kualitas pekerjaan, ketetapan waktu, inisiatif, kemampuan serta komunikasi.

\section{Pengaruh Antara Motivasi Terhadap Kinerja Pegawai}

Dilihat di atas maka dapat diketahui bahwa motivasi memiliki pengaruh dengan kinerja pegawai karena seperti yang dikatakan oleh T. R.Mitchel dalam buku Sedarmayanti (2001:51) yang berjudul Manajemen Sumber Daya Manusia dan Produktivitas Kerja, menjelaskan bahwa :

Maksudnya untuk mendapatkan gambaran tentang kinerja seseorang, maka diperlukan pengkajian khusus tentang kemampuan dan motivasi.
Yang mana hal yang hampir sama juga dikatakan oleh Gibson yang dikutip oleh Pasolong (2007:176), dalam bukunya yang berjudul Teori Administrasi Publik menyatakan bahwa : "Kinerja seseorang ditentukan oleh kemampuan dan motivasinya untuk melaksanakan pekerjaan.

\section{KONSEP PENDEKATAN SISTEM MOTIVASI DENGAN KINERJA KARYAWAN}

\begin{tabular}{|c|c|c|}
\hline $\begin{array}{l}\text { INPUT } \\
\text { Sumber daya yang } \\
\text { terdiri dari Six M } \\
: \\
\text { 1. Man } \\
\text { 2. Money } \\
\text { 3. Method } \\
\text { 4. Materials } \\
\text { 5. Machine } \\
\text { 6. Market }\end{array}$ & $\begin{array}{l}\text { PROSES } \\
\text { Prinsip-prinsip } \\
\text { dalam memotivasi } \\
\text { kerja pegawai } \\
\text { adalah sebagai } \\
\text { berikut : } \\
\text { 1. Prinsip }\end{array}$ & $\begin{array}{l}\text { Ukuran kinerja } \\
\text { pegawai } \\
\text { dilihat dari: } \\
\text { 1. Kualitas Kerja } \\
\text { (Quality of work) } \\
\text { 2. Ketetapan } \\
\text { Waktu } \\
\text { (Pomptnees) } \\
\text { 3. Inisiatif (Initiative) }\end{array}$ \\
\hline & $\begin{array}{l}\text { 2. Prinsip } \\
\text { komunikasi; } \\
\text { 3. Prinsip } \\
\text { mengakui andil } \\
\text { bawahan; } \\
\text { 4. Prinsippendelega } \\
\text { sian wewenang; }\end{array}$ & $\begin{array}{l}\text { mpuan } \\
\text { (Capab } \\
\text { ility) } \\
\text { 5. Komunikasi } \\
\text { (Communication }\end{array}$ \\
\hline \multicolumn{3}{|l|}{ FEED BACK } \\
\hline
\end{tabular}

\section{Keterangan :}

\section{Input}

Terdiri dari sumber-sumber manajemen (the six m) yaitu sebagai berikut :

\section{a. Man (Manusia)}

Sumber daya manusia merupakan faktor dari sebuah proses pencapaian tujuan organisasi yang sangat penting keberadaannya karena manusia (para pegawai) merupakan kunci keberhasilan dari pencapaian sasaran organisasi pada PT.Dalia Kusuma Bandung.

b. Money (Biaya)

Biaya dalam bentuk uang merupakan faktor yang tidak kalah pentingnya karena merupakan unsur yang memodali seluruh kegiatan yang dilaksanakan pada PT.Dalia Kusuma Bandung.

c. Methode (Metode) 
Metode atau dasar penggunaan dari sumber-sumber yang sudah ada pada PT.Dalia Kusuma Bandung.

d. Machine (Mesin)

Merupakan unsur untuk menciptakan sesuatu yang digunakan untuk pencapaian tujuan daripada PT.Dalia Kusuma Bandung.

\section{e. Material (Bahan Baku)}

Merupakan salah satu alat kerja untuk mendukung tercapainya suatu keberhasilan dalam melakukan pekerjaan yang akan dikerjakannya, karena dengan bahan-bahan yang memenuhi atau tersedia, maka seluruh pekerjaan akan menghasilkan kinerja kerja yang baik.

f. Market (Pemasaran)

Merupakan unsur yang menjadi alat untuk mendistribusikan semua jenis pekerjaan yang dihasilkan oleh para pegawai PT.Dalia Kusuma Bandung.

\section{Proses}

Dalam suatu proses semua sumber-sumber dari input diupayakan untuk dapat dimanfaatkan dalam melaksanakan motivasi yang berdasarkan prinsip-prinsip motivasi yang ditujukan untuk memenuhi indikator dari kinerja pegawai. Dalam hal ini, motivasi yang dilakukan berdasarkan prinsip-prinsip motivasi kinerja pegawai.

\section{Output}

Merupakan hasil yang teah dicapai melalui proses kerja yang dilakukan oleh para pegawai PT.Dalia Kusuma Bandung, serta didukung oleh sumber daya lainnya, sehingga diperoleh suatu hasil kerja. Apabila indikator-indikator kinerja pegawai telah dapat dilaksanakan dengan memanfaatkan input yang ada, maka kinerja pegawai akan meningkat

\section{Feedback}

Pencapaian target dalam penyelesaian surat izin mendirikan bangunan pada PT.Dalia Kusuma Bandung, diharapkan dapat memberikan umpan balik terhadap input yang berupa kesinambungan unsur-unsur yang terdapat dalam input, sehingga dapat diupayakan agar lebih berdaya guna. Umpan balik yang diharapkan adalah memperbaiki kekurangan di dalam pelaksanaan kinerja pegawai PT.Dalia Kusuma Bandung.
Permasalahan yang diteliti dalam penelitian ini adalah penulis ingin melihat bagaimana pengaruh motivasi terhadap kinerja karyawan pada PT. Dalia Kusuma Bandung. Untuk mendapatkan data sehubungan dengan permasalahan yang diteliti tersebut, penulis menggunakan metode penelitian kuantitatif. Karena maksud dari metode kuantitatif adalah metode metode penelitian yang di angkakan (scoring), karena terdapat dalam skala pengukuran. Dimana pengukuran itu berdasarkan pernyataan yang memerlukan jawaban, yang umumnya seperti sangat setuju, setuju, kurang setuju atau ragu - ragu, tidak setuju, dan sangat tidak setuju. Dan biasanya masing - masing diberikan angka sebagai penilaian (scoring) 5 untuk sangat setuju, dan 1 untuk sangat tidak setuju. Data dari penelitian kuantitatif dinyatakan dalam bentuk angka, presentase, dan desimal.

Berdasarkan judul Penelitian ini yaitu "Pengaruh Motivasi Terhadap Kinerja Karyawan PT. Dalia Kusuma Bandung", maka variabel - variabel yang diteliti dapat dibedakan menjadi dua yaitu :

1. Variabel Independen atau Variabel Bebas (Variabel $\mathrm{X})$

Sugiyono (2011 : 39) mengemukakan bahwa variabel bebas merupakan variabel yang mempengaruhi menjadi sebab perubahannya atau timbulnya variabel dependen (terikat). Dalam hal ini variabel bebas yang akan berkaitan dengan masalah yang akan diteliti adalah data yang menjadi variabel bebas (variabel $\mathrm{X}$ ) adalah Motivasi.

2. Variabel Dependen atau Variabel Terikat (Variabel Y)

Sugiyono (2011: 39) mengemukakan variabel terikat merupakan variabel yang mempengaruhi atau yang menjadi akibat karena adanya variabel independen (bebas). Dalam penelitian ini yang menjadi variabel terikat adalah kinerja karyawan PT. Dalia Kusuma Bandung.

Tabel 1 Operasional Variabel

\begin{tabular}{|c|c|c|c|c|}
\hline $\begin{array}{c}\text { Variab } \\
\text { el }\end{array}$ & Definisi Variabel & Indikator & $\begin{array}{c}\text { Skal } \\
\text { a }\end{array}$ & No.Item \\
\hline \multirow{4}{*}{$\begin{array}{c}\text { Motivas } \\
\text { i (X) }\end{array}$} & & Keinginan & \multirow{4}{*}{$\begin{array}{l}\text { O } \\
\text { R } \\
D \\
\text { I } \\
\mathrm{N} \\
\mathrm{A} \\
\mathrm{L}\end{array}$} & $\begin{array}{l}1 \\
2\end{array}$ \\
\hline & & Pribadi & & $\begin{array}{l}3 \\
4\end{array}$ \\
\hline & & Tindakan & & $\begin{array}{l}5 \\
6\end{array}$ \\
\hline & & Kepuasan & & $\begin{array}{l}7 \\
8\end{array}$ \\
\hline
\end{tabular}

\section{METODOLOGI}




\begin{tabular}{|c|c|c|c|c|}
\hline & $\begin{array}{c}\text { Menurut Effendi } \\
\text { yang dikutip oleh } \\
\text { Manullang dan } \\
\text { Manullang } \\
\text { (2004:193) dalam } \\
\text { bukunya } \\
\text { Manajemen } \\
\text { Personalia } \\
\text { mengemukakan } \\
\text { bahwa: Motivasi } \\
\text { adalah kegiatan } \\
\text { memberikan } \\
\text { dorongan pada } \\
\text { seseorang atau diri } \\
\text { sendiri untuk } \\
\text { mengambil suatu } \\
\text { tindakan yang } \\
\text { dikehendaki. Jadi } \\
\text { motivasi berarti } \\
\text { membangkitkan } \\
\text { seseorang atau diri } \\
\text { sendiri untuk } \\
\text { berbuat sesuatu } \\
\text { dalam rangka } \\
\text { mencapai suatu } \\
\text { kepuasan dan } \\
\text { tujuan. }\end{array}$ & Dorongan & & $\begin{array}{c}9 \\
10\end{array}$ \\
\hline \multirow{9}{*}{$\begin{array}{c}\text { Kinerja } \\
\text { Karya } \\
\text { wan } \\
(\mathrm{Y})\end{array}$} & \multirow{9}{*}{$\begin{array}{l}\text { Kinerja adalah } \\
\text { hasil kerja } \\
\text { secara kualitas } \\
\text { maupun } \\
\text { kuantitas yang } \\
\text { dicapai oleh } \\
\text { seorang } \\
\text { karyawan dalam } \\
\text { melaksanakan } \\
\text { tugasnya sesuai } \\
\text { dengan } \\
\text { tanggung jawab } \\
\text { yang diberikan } \\
\text { kepadanya. A.A } \\
\text { Anwar Prabu } \\
\text { Mangkunegara, } \\
\text { 2004: 67) }\end{array}$} & $\begin{array}{l}\text { Tanggung } \\
\text { Jawab }\end{array}$ & \multirow{9}{*}{$\begin{array}{l}\mathrm{O} \\
\mathrm{R} \\
\mathrm{D} \\
\mathrm{I} \\
\mathrm{N} \\
\mathrm{A} \\
\mathrm{L}\end{array}$} & 1 \\
\hline & & Prestasi Kerja & & 2 \\
\hline & & $\begin{array}{l}\text { Pengetahuan } \\
\text { Pekerjaan }\end{array}$ & & 3 \\
\hline & & Kesadaran & & 4,8 \\
\hline & & kreativitas & & 5 \\
\hline & & Kerjasama & & 6 \\
\hline & & kepentingan & & 7 \\
\hline & & Semangat & & 9 \\
\hline & & Ketaatan & & 10 \\
\hline
\end{tabular}

Teknik yang digunakan penulis dalam mengambil sampel adalah pengambilan sampel jenuh. Menurut Sugiyono "Sampling Jenuh adalah teknik penentuan sampel apabila semua anggota populasi digunakan sebagai sampel" (Sugiyono, 2012 : 96). Karena jumlah karyawan yang diteliti kurang dari 30, maka penulis menggunakan sampling jenuh. Yaitu seluruh karyawan dijadikan objek penelitian sejumlah 18 orang.

Menurut Victorianus Aries Siswanto (2012:43), "Sampel adalah sebagian dari populasi yang karakteristiknya hendak diselidiki".

Sedangkan menurut SLOVIN cara menghitung jumlah sampel adalah sebagai berikut (Sarwono,2006):

$$
n=\frac{\mathrm{N}}{\mathrm{N}(\mathrm{d})^{2}+1}
$$

Keterangan :

$\mathrm{n}$ : jumlah sampel

$\mathrm{N}$ : populasi

$\mathrm{d}$ : derajat kebebasan
Dalam penulisan tugas akhir ini penulis menggunakan beberapa teknik pengumpulan data diantaranya :

1. Observasi

2. Kuesioner / Angket

3. Studi Kepustakaan

4. Wawancara

Untuk mengetahui uji statistik anatara variabel $\mathrm{X}$ dan variabel Y digunakan analisis korelasi, sedangkan metode dan teknik dalam korelasi yang populer digunakan adalah korelasi rank spearman atau variabel berskala ordinal.

\section{Skala Pengukur}

Skala pengukur yang digunakan dalamm penelitian ini adalah dengan menggunakan skala likert. Menurut Ridwan dan Akdon (2007 : 12) "skala likert adalah skala yang didasarkan pada ranking yang diurutkan dari jenjang yang lebih tinggi sampai jenjang yang terendah atau sebaliknay". Dengan skala likert, maka variabel yang akan diukur dijabarkan menjadi indikator variabel, kemudian indikator tersebut dijadikan sebagai titik tolak ukur untuk menyusun item - item instrumen yang dapat berupa pernyataan.

Sedangkan skala likert menurut Djaali (2008 : 28) adalah "skala yang dapat dipergunakan untuk mengukur sikap, pendapat, dan persepsi seseorang atau sekelompok orang tentang suatu gejala atau fenomena pendidikan". Kemudian Sugiyono (2006 : 86) menyatakan bahwa "skala likert adalah jawaban setiap instrumen yang menggunakan skala likert mempunyai gradasi dari sangat positif sampai sangat negatif". Yang dapat berupa kata - kata dengan diberi skor, misalnya :
a. SS (Sangat Setuju)
b. $\quad$ S (Setuju)
c. $\quad$ KS (Kurang Stuju / Ragu - ragu)
d. TS (Tidak Setuju)
e. $\quad$ STS (Sangat Tidak Setuju)

Setiap jawaban memiliki skor seperti tercantum dalam tabel di bawah ini :

\section{Tabel 2 Bobot Nilai Kuesioner}

\begin{tabular}{|c|c|c|}
\hline No. & Keterangan & Skor / Nilai \\
\hline 1 & Sangat Setuju & 5 \\
\hline 2 & Setuju & 4 \\
\hline 3 & $\begin{array}{c}\text { Kurang Setuju / Ragu - } \\
\text { ragu }\end{array}$ & 3 \\
\hline 4 & Tidak Setuju & 2 \\
\hline 5 & Sangat Tidak setuju & 1 \\
\hline
\end{tabular}

Sumber : Sugiyono (2006:86) 
Instrumen yang digunakan dalam kuesioner ini adalah pemberian tanda cheklis $(\sqrt{ })$ untuk jawaban yang dipilih.

2. Analisis Korelasi

Dalam penelitian ini penulis ingin mengetahui uji determinasi terhadap peningkatan kinerja karyawan di PT. Dalia Kusuma Bandung dengan menggunakan koefisien Rank-Spearman. Menurut Sugiyono (2007:245) analisis koefisien "rank spearman adalah suatu ukuran yang mendeskripsikan hubungan antara variabel yang didukung secara substansi atau teoritis".

a. Rumus untuk data yang tidak mempunyai nilai kembar

$$
\begin{gathered}
r s=1-\frac{6 \sum\left(R(X i)-R(Y i)^{2}\right)}{n\left(n^{2}-1\right)} \\
r s=1-\frac{6 \sum d i^{2}}{n\left(n^{2}-1\right)}
\end{gathered}
$$

b. Rumus untuk data yang memiliki Nilai kembar

$$
r s=\frac{\sum x^{2}+\sum y^{2}+\sum d i^{2}}{\sqrt[2]{\sum x^{2}-\sum y^{2}}}
$$

Korelasi Rank Spearman dinyatakan dalam rumus : Dimana :

Rs : Koefisien korelasi rank spearman.

$\mathrm{R}(\mathrm{Xi}), \mathrm{R}(\mathrm{Yi}) \quad$ : Rangkaian skor data variabel $\mathrm{X}$ dan variabel $\mathrm{Y}$.

n : Jumlah data.

Untuk mengetahui seberapa besar hubungan antara variabel X dan variabel Y tersebut diperlukan suatu tafsiran yang akan diperjelas dalam batasan - batasan seperti kriteria di bawah ini.

Tabel 3

Pedoman Untuk Memberikan Kategori Koefisien Korelasi

\begin{tabular}{|c|c|}
\hline $\begin{array}{c}\text { Interval } \\
\text { Koefisien } \\
\text { Korelasi }\end{array}$ & Tingkat Hubungan \\
\hline $0,00-0,199$ & Sangat Tidak Setuju \\
\hline $0,20-0,399$ & Sangat Setuju \\
\hline $0,40-0,599$ & $\begin{array}{c}\text { Kurang Setuju / } \\
\text { Ragu - ragu }\end{array}$ \\
\hline $0,60-0,799$ & Setuju \\
\hline $0,80-1,000$ & Sangat Tidak Setuju \\
\hline
\end{tabular}

Sumber : Sugiyono, $(2003: 183)$

Jadi analisis ini digunakan ntuk mengetahui pengaruh motivasi terhadap kinerja karyawan di PT.Dalia Kusuma Bandung.
3. Analisis Determinasi

Analisis determinasi digunakan untuk "mengetahui presentase pengaruh yang sudah di uji memakai uji korelasi. Nilai koefisien determinasi $\left(\mathrm{R}^{2}\right)$ menunjukan presentase pengaruh semua variabel independen terhadap variabel dependen. Menjelaskan besarnya kontribusi yang diberikan variabel independen dan dependen", Sugiyono (2005:250).

Rumus koefisien determinasi dapat ditunjukan sebagai berikut :

$\mathrm{KP}=\mathrm{r}^{2} \times 100 \%$

Dimana :

KP : Koefisien penentu atau koefisien determinasi

$$
\mathrm{r}^{2} \text { : Koefisien Korelasi }
$$

\section{HASIL DAN PEMBAHASAN}

Sikap motivasi sangat penting bagi suatu perusahaan dalam rangka mewujudkan suatu tujuan perusahaan, hal ini sesuai dengan penjelasan Menurut Effendi yang dikutip oleh Manullang dan Manullang (2004:193) dalam bukunya Manajemen Personalia mengemukakan bahwa : Motivasi adalah kegiatan memberikan dorongan pada seseorang atau diri sendiri untuk mengambil suatu tindakan yang dikehendaki. Jadi motivasi berarti membangkitkan seseorang atau diri sendiri untuk berbuat sesuatu dalam rangka mencapai suatu kepuasan dan tujuan.

. Dengan adanya motivasi pada setiap karyawan yang ada di dalam perusahaan tersebut, akan menjadikan perusahaan itu menjadi maju. karena setiap karyawan yang mempunyai motivasi dalam melakukan pekerjaan dapat menyelesaikan tugas-tugas yang ada di dalam perusahaan tersebut walaupun tidak secara keseluruhan menghasilkan pekerjaan yang sempurna. Tetapi dalam jangka waktu tertentu karyawan akan melaksanakan pekerjaannya menjadi lebih baik.

Berdasarkan hasil rekapitulasi variabel $\mathrm{X}$ diatas dapat dilihat Saya merasa senang karena karyawan di perusahaan ini bisa menerima saya sebagai partner yang baik dan Saya selalu dilibatkan dalam pertemuan atau rapat dalam mengambil keputusan perusahaan. memiliki nilai tertinggi dibanding dengan yang lain yaitu sebesar 81, lalu Saya merasa senang bila pengabdian saya selama bekerja di perusahaan ini di akui oleh atasan memiliki nilai sebesar 77. Pada tingkat ketiga sebesar 76, yaitu Saya merasa tertantang untuk menyelesaikan tugas yang diberikan. Pada tingkat keempat sebesar 75 yaitu Saya merasa bahwa kebutuhan dasar seperti untuk dapat makan secara wajar sudah terpenuhi, Atasan saya selalu memberikan pujian apabila saya menjalankan tugas pekerjaan dengan hasil memuaskan dan Perusahaan memberikan kesempatan bagi karyawan untuk mengembangkan potensi yang ada pada dirinya untuk lebih maju. Dan pada tingkat ke lima Saya merasa 
bahwa dengan bekerja di perusahaan ini,kebutuhan perumahan yang wajar sudah dapat terpenuhi sebesar 73. Pada posisi terendah kedua yaitu Bekerja pada perusahaan ini, dapat menjamin kehidupan saya di hari tua sebesar 72. Secara keseluruhan variabel $\mathrm{X}$ tergolong pada daerah baik akan tetapi yang menjadi posisi terendah berada pada Saya merasa tenang dalam bekerja karena tersedianya jaminan kesehatan dari perusahaan ini sebesar 62, hal ini yang menjadi suatu permasalahan yang timbul dalam motivasi kerja.

Berdasarkan hasil perhitungan diambil kesimpulan bahwa data yang diperoleh dari hasil penelitian mengenai Motivasi kerja para karyawan di PT. Dalia Kusuma Bandung ialah sebesar 83 dan terletak pada daerah sangat baik, hal ini membuktikan bahwa pelaksanaan Motivasi kerja para karyawan sudah tergolong sangat baik.

Berdasarkan hasil rekapitulasi variabel Y diatas dapat dilihat saya selalu berusaha untuk menyelesaikan tugas dengan penuh rasa tanggung jawab untuk mencapai hasil yang maksimal, Saya lebih mengutamakan kepentingan kelompok daripada kepentingan pribadi dalam menyelesaikan pekerjaan dan Saya selalu hadir tepat waktu sesuai dengan jadwal yang sudah ditetapkan di tempat kerja memiliki nilai tertinggi dibanding dengan yang lain yaitu sebesar 78, lalu Saya selalu bersedia untuk bekerja sama dengan sesama anggota perusahaan mempunyai nilai sebesar 77. Pada tingkat ketiga sebesar 76, yaitu Saya selalu berusaha menyelesaikan tugas-tugas yang diberikan sesuai dengan target waktu kerja yang telah ditentukan, Pengetahuan akan pekerjaan dapat membantu saya dalam mengatasi permasalahan yang muncul pada saat bekerja dan Saya selalu fokus menyelesaikan pekerjaan,walaupun tidak ada atasan di perusahaan. Pada tingkat keempat sebesar 74 yaitu Kreativitas yang tinggi dapat membantu saya mencapai hasil kerja yang lebih baik, Karyawan memiliki semangat untuk melaksanakan tugas-tugas baru yang diberikan oleh perusahaan. Secara keseluruhan variabel $\mathrm{X}$ tergolong pada daerah baik akan tetapi yang menjadi posisi terendah berada pada Saya dapat mengerjakan pekerjaan dengan efektif dan efisien sehingga tidak perlu banyak instruksi dan umpan balik dari atasan saya sebesar 73 , hal ini yang menjadi suatu permasalahan yang timbul dalam kinerja karyawan.

Skor yang Diperoleh :

$\begin{array}{lll}\text { Jumlah Skor : } & 52 & \text { Responden Menjawab SS } \\ \text { Jumlah Skor : } & 116 & \text { Responden Menjawab S } \\ \text { Jumlah Skor : } & 12 & \text { Responden Menjawab KS } \\ \text { Jumlah Skor : } & 0 & \text { Responden Menjawab TS } \\ \text { Jumlah Skor : } & 0 & \text { Responden Menjawab STS }\end{array}$

Total Skor

Jumlah skor yang diperoleh dari hasil penelitian adalah 760. Skor Ideal $5 \times 18 \times 10=900$. Maka jumlah skor yang diperoleh melalui pengumpulan data adalah sebesar $(760 / 900) \times 100 \%=84,45 \%$, dan terletak pada daerah sangat baik, hal ini membuktikan bahwa pelaksanaan kinerja karyawan para karyawan sudah tergolong sangat baik.

\section{Analisis Koefisien Korelasi Rank Spearman}

Adanya pengaruh Motivasi sangatlah penting guna meningkatkan kinerja karyawan di PT. Dalia Kusuma Bandung. Dengan adanya motivasi yang ditetapkan maka karyawan akan mempunyai kinerja yang baik sehingga akan berdampak pada hasil kerja. Untuk melihat pengaruh motivasi terhadap kinerja karyawan di PT.Dalia Kusuma Bandung maka penulis mencoba untuk melakukan analisis melalui koefisien korelasi rank spearman dengan mengolah hasil kuesioner dari 18 responden yang merupakan sampel dari karyawan di PT. Dalia Kusuma Bandung, yang hasilnya adalah :

$$
\begin{aligned}
& \text { Dik : } \sum \mathrm{T}_{\mathrm{x}}=37 \\
& \begin{aligned}
\sum \mathrm{X}^{2} & =\frac{n^{3}-n}{12}-\sum \mathrm{T}_{\mathrm{x}}=12 \\
\sum \mathrm{X}^{2} & =\frac{18^{3}-18}{12}-37 \\
\sum \mathrm{X}^{2} & =\frac{5.832-18}{12}-37 \\
\sum \mathrm{X}^{2} & =484,5-37
\end{aligned} \\
& \sum X^{2}=447,5 \\
& \begin{aligned}
\sum \mathrm{Y}^{2} & =\frac{n^{3}-n}{12}-\sum \mathrm{T}_{\mathrm{y}} \\
\sum \mathrm{Y}^{2} & =\frac{18^{3}-18}{12}-37 \\
\sum \mathrm{Y}^{2} & =\frac{5.832-18}{12}-12 \\
\sum \mathrm{Y}^{2} & =484,5-12
\end{aligned} \\
& \sum \mathrm{Y}^{2}=472,5 \\
& r_{s}=\frac{\sum X^{2}+\sum Y^{2}-\sum d_{i}^{2}}{\sqrt{\sum X^{2} \sum Y^{2}}} \\
& r_{s}=\frac{447,5+472,5-553}{\sqrt{(447,5)(472,5)}} \\
& r_{s}=\frac{367}{\sqrt{211.443,75}} \\
& r_{s}=\frac{367}{459,83} \\
& r_{s}=0,798
\end{aligned}
$$

$$
=5 \times 52=260
$$

$=4 \times 116$ Berqgðarkan hasil perhitungan diatas $=3 \times$ maka perolehzon hasil bahwa koefisien korelasi $=2 \times$ rank spearman antara Motivasi terhadap $=1 \times$ kinerja karyawan adalah sebesar 0,798, maka derajat hubuther Motivasi terhadap kinerja karyawan yang menghasilkan jumlah korelasi rank spearman sebesar 0,798 termasuk golongan hubungannya kuat. 


\section{KESIMPULAN}

Berdasarkan hasil penelitian yang dilakukan oleh penulis di PT.Dalia Kusuma Bandung yang mengambil permasalahan tentang pengaruh motivasi terhadap kinerja karyawan. Maka dapat ditarik kesimpulan sebagai berikut :

1. Dari hasil perhitungan yang dilakukan, untuk mengetahui motivasi kerja karyawan di PT.Dalia Kusuma Bandung melalui pembagian kuesioner kepada 18 responden diperoleh nilai skor aktual sebesar 747 dengan skor ideal sebesar 900 sehingga dapat diketahui persantase motivasi karyawan yaitu (747 / 900) $\times 100 \%=83 \%$, berarti Motivasi kerja karyawan sudah mencapai 83\% (Sangat Baik).

2. Dari hasil perhitungan yang dilakukan, untuk mengetahui kinerja karyawan di PT. Dalia Kusuma Bandung melalui pembagian kuesioner kepada 18 responden diperoleh nilai skor aktual sebesar 760 dengan skor ideal sebesar 900 sehingga dapat diketahui persantase disiplin karyawan yaitu $(760$ / 900) $\mathrm{x} 100 \%=84,45 \%$, berarti motivasi kerja karyawan sudah mencapai $84,45 \%$ (Sangat Baik).

3. Sedangkan untuk pengaruh motivasi kerja terhadap kinerja karyawan yang telah didapatkan oleh penulis di PT. Dalia Kusuma Bandung melalui pembagian kuesioner kepada 18 responden dan dari hasil yang telah dideskripsikan, antara lain : dengan menggunakan analisis koefisien korelasi rank spearman (r) dan koefisien determinasi (R) maka didapat hasilnya bahwa motivasi kerja memiliki pengaruh yang kuat terhadap kinerja karyawan yaitu sebesar 0,798 serta besarnya hubungan berdasarkan hasil koefisien determinasi yaitu sebesar $63,68 \%$ dan sisanya sebesar $36,32 \%$ dipengaruhi oleh faktorfaktor lain yang tidak diteliti oleh penulis seperti lingkungan kerja, promosi dan lain-lain.

4. Beberapa permasalahan yang dihadapi dalam upaya pengaruh Motivasi terhadap kinerja karyawan di PT. Dalia Kusuma Bandung diantaranya, Karyawan merasa tidak tenang dalam bekerja karena belum tersedianya jaminan kesehatan dari perusahaan ini dan Bekerja pada perusahaan ini, belum dapat menjamin kehidupan karyawan di haritua.

5. Upaya Pemecahan yang Dilakukan untuk Mengatasi Masalah motivasi Terhadap Kinerja diantaranya, Perusahaan lebih memperhatikan kebutuhan para karyawan dalam masalah jaminan kesehatan yang dapat menunjang pekerjaan, Perusahaan lebih memperhatikan masalah kesejahteraan para karyawan dengan tunjangan di hari tua, Perusahaan memperhatikan masalah sarana dan prasarana P2K3 ( Pertolongan Pertama Korban Kecelakaan Kerja ) di tempat kerja, dan Pihak perusahaan memberikan pelatihan - pelatihan bagi karyawan untuk mengasah kemampuan dan kecakapan serta pengalaman yang diperlukan sehingga dapat menyelesaikan pekerjaanya dengan baik.

\section{KAJIAN PUSTAKA}

Edwin B. Flippo (2002) ,Manajemen Sumber Daya Manusia,Bambang Wahyudi.

A. A Anwar Prabu Mangkunegara. 2001. Manajemen Sumber Daya Manusia. Edisi Revisi.Cetakan Keenam Belas. Jakarta. PT. Bumi Aksara.

Bambang W. 2002. Manajemen Sumber Daya Manusia. Bumi Aksara. Jakarta.

Ferdinand, Augusty. 2006. Metode Penelitian Manajemen. Edisi 2. BP Universitas Diponegoro. Semarang.

Handoko,T Hani.2001. Manajemen Personalia dan Sumber DayaManusia. Edisi 2 BPFE. Yogyakarta.

Hasibuan, Malayu S.P. 2000. Manajemen Sumber Daya Manusia. Bumi Aksara. Jakarta.

M. Manullang, Marihot Manullang. 2001. Manajemen Sumber DayaManusia. Yogyakarta. BPFE.

Nasir M, 2000. Metodologi penelitian. Eresco. Jakarta. Sastrohadiwiryo. 2001. Manajemen Sumber Daya Manusia. Edisi Revisi.Cetakan Keenam Belas. Jakarta. PT. Bumi Aksara.

Simamora, Henry. 2004. Manajemen Sumber Daya Manusia. STIE YPKN Yogyakarta. Yogyakarta.

Sinungan Muchdarsyah. 2000. Metodologi Penelitian. Eresco. Jakarta.

Sugiyono. 2011. Metode PenelitianAdministrasi. Cv Alfabeta.Bandung.

Sutrisno, Edy. 2009. Manajemen Sumber Daya Manusia. Prenada Media Group. Jakarta.

Veranita, Mira.2012. Pengaruh Pemberdayaan Pegawai terhadap Efektivitas Kerja pada PT Pos Indonesia (Persero), Jurnal Bisnis Wirausaha ISSN 1693-234X Volume 7 No.1

Yuniarsih dan Suwatno. 2008. Manajemen Sumber Daya Manusia. Alfabeta. Bandung. 